\title{
Contamination by Remazol Red Brilliant Dye and Its Impact in Aquatic Photosynthetic Microbiota
}

\author{
Mariana Lopes de Sousa \\ UNESP - Univ Estadual Paulista, Av. 24 ${ }^{\text {a }}$ \\ 1515 Postal Code: 13506-900, Rio Claro-SP, Brazil \\ Tel: (55)19-3526-4191Ｅ-mail: maree_mitsu@yahoo.com.br \\ Peterson Bueno de Moraes \\ DTSA, FT/UNICAMP, R. Paschoal Marmo \\ 1888 - Jd. Nova Itália, Postal Code: 13484-332, Limeira-SP, Brazil \\ E-mail: peterson@ft.unicamp.br \\ Paulo Renato Matos Lopes \\ UNESP - Univ Estadual Paulista, Av. 24A, 1515 - Bela Vista \\ Postal Code: 13506-900 Rio Claro-SP, Brazil \\ Tel: (55)19-3526-4191Ｅ-mail: mlopes.paulo@yahoo.com.br
}

Renato Nallin Montagnolli

UNESP - Univ Estadual Paulista, Av. 24A, 1515 - Bela Vista

Postal Code: 13506-900 Rio Claro-SP, Brazil

Tel: (55)19-3526-4191_E-mail: renatonm3@gmail.com

Dejanira de Fransceschi de Angelis

UNESP - Univ Estadual Paulista, Av. 24A, 1515 - Bela Vista

Postal Code: 13506-900, Rio Claro-SP, Brazil

Tel: (55)19-3526-4191Ｅ-mail: dangelis@rc.unesp.br

\author{
Ederio Dino Bidoia (Corresponding Author) \\ UNESP - Univ Estadual Paulista, Av. 24A, 1515 - Bela Vista \\ Postal Code: 13506-900, Rio Claro-SP, Brazil \\ Tel: (55)19-3526-4191Ｅ-mail: ederio@rc.unesp.br
}


Received: September 4, 2012

doi:10.5296/emsd.v1i2.2512
Accepted: September 20, 2012

URL: http://dx.doi.org/10.5296/emsd.v1i2.2512

\begin{abstract}
The purpose of this work was to evaluate the heterogeneity and diversity of algae according to an aquatic environment polluted by Remazol Red Brilliant dye. Methodology followed Winogradsky columns technique, which describes a microecosystem in a glass container. Two columns were prepared: one control and another with Remazol Red Brilliant dye simulating a contaminated environment. The experiment was under illumination to provide light energy to photosynthetic organisms and alteration in two columns were observed and quantified: algae development and color changes. Results demonstrated that $\mathrm{pH}$ remained constant in control column; however the initial $\mathrm{pH}$ changed in contaminated column. A higher $\mathrm{pH}$ observed at the bottom after 48 days showed microbial activity in dye biodegradation, which was corroborated by minor absorbance value at Remazol Red Brilliant peak (541.5 $\mathrm{nm})$. Moreover, control column presented higher algae growth since the beginning owing to the dye absence and 12 different families were identified in two Winogradsky column. This analysis concluded that, despite the greater diversity found in $\mathrm{B}$, algae biomass production was much smaller compared to column without the dye. Therefore, Remazol Red Brilliant presence would affect the food chain in aquatic environments and consequently causes an ecological imbalance by the textile effluent impact.
\end{abstract}

Keywords: Algae, Textile effluent, Water, Pollution, Winogradsky column

\title{
1. Introduction
}

Human activities including the discharge of effluents rich in nutrients promote aquatic ecosystems eutrophication (Tundisi and Matsumura-Tundisi, 1992; Biggs, 2006). Effluents from textile industry could make wastewater toxic (Robinson et al., 2001). In these cases water is unfit for human consumption and causes ecosystem imbalance within any living being a link in the food chain, even small such as the phytoplankton (Rocha, 1992).

Algae like phytoplankton are the basis of many food chains in the role of primary producers, but in excess can also seriously affect water quality (Rocha, 1992) because some species produce toxic substances (Beyruth et al., 1992). Algae are organisms of varied nature, as they may belong to Plantae, Metazoa or Bacteria kingdoms (Brusca and Brusca, 2003; Bicudo and Menezes, 2006). These organisms have wide distribution, being present in almost all rivers and lakes, and provide a large number of species which are important in the organic matter production in ecosystems (Klaine and Lewis, 1995). According to Bicudo and Menezes (2006), algae are organisms with characteristics, ecology and behavior so distinct within each other that make hard their identification.

Measuring pollution in aquatic environments, algae are 50\% more sensitive to contaminants compared to organisms commonly used in toxicological tests (Klaine and Lewis, 1995). 


\section{Macrothink}

For preservation and maintenance of aquatic ecosystems and reservoirs to supply the population, an important tool is to understand the wastewater effects in algae community when they are released, such as industrial effluents.

In this context, Winogradsky column appears as a technique to evaluate these effects in aquatic microbiota. Within the column, microorganism's growth, such as the algae, and their preferential distribution can be checked (Pigage, 1985). Contamination effects in aquatic ecosystems can be inferred by knowing the phytoplankton constitution (Pérez, 2008). Thus, environmental studies in this field can be applied to treat industrial effluents, as the ones from textile factory.

Sulphonated vinyl reactive dyes (azo chromophore group $\mathrm{N}=\mathrm{N}$ ) represent about $60 \%$ of the dyes used in textile industry (Catanho et al., 2006). These compounds are soluble in water and usually have high concentration in wastewater discharge (reaching up to 50\%) representing the dye percentage that do not fix in textile fibers (Al-Degs et al., 2000).

The aim of this study was to evaluate the effect of a simulated textile effluent on phytoplankton by Winogradsky columns, which deal with a microecosystem in a glass container composed of soil (taken of the river bottom), water and nutrients.

\section{Experimental}

\subsection{Winogradsky Column}

Two Winogradsky columns were prepared using glass containers of $7 \mathrm{~L}$ measuring $50 \mathrm{~cm} \mathrm{X}$ $20 \mathrm{~cm} \mathrm{X} 20 \mathrm{~cm}$ (Figure 1). As substrate for these columns was used Atibaia river soil near from a petroleum refinery (REPLAN, Petrobrás - Brazil). The water was collected from Ribeirão Claro near form a water treatment station input (Rio Claro, SP - Brazil).

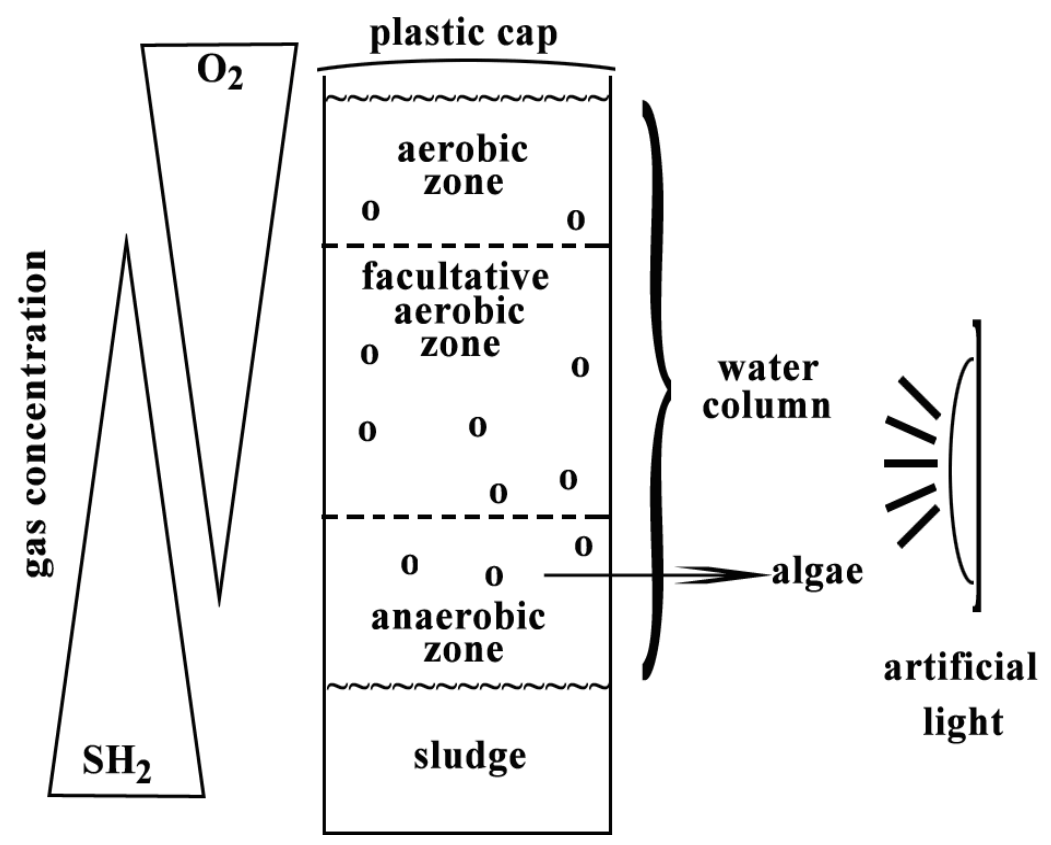

Figure 1. Winogradsky column diagram 


\section{Macrothink}

First column was labeled as "control” (A) containing $500 \mathrm{~g}$ of soil (mud), nutrients and $5.0 \mathrm{~L}$ of water. Second column named "contaminated" (B) presented 500 g of soil, nutrients and 4.5 $\mathrm{L}$ of water more $0.5 \mathrm{~L}$ of simulated textile effluent.

According to Sousa et al. (2012) the simulated textile effluent was composed of distilled water, sodium chloride $\left(10,000 \mathrm{mg} \mathrm{L}^{-1}\right)$, sodium carbonate $\left(1,320 \mathrm{mg} \mathrm{L}^{-1}\right)$ and Remazol Brilliant Red dye (200 mg L ${ }^{-1}$ ), which belongs to reactive dyes class (Figure 2). This solution showed intense dark red color and $\mathrm{pH}$ 3.5.

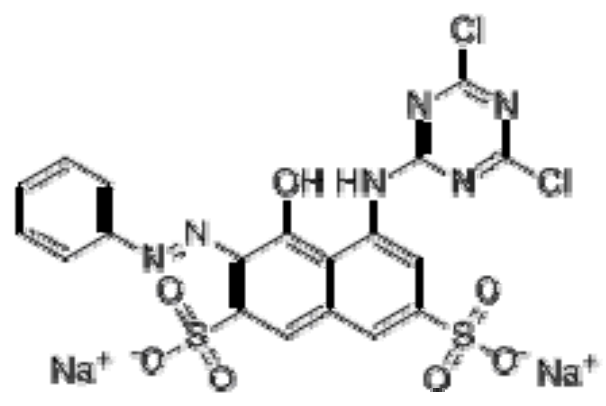

Figure 2. Molecule of Remazol red brilliant dye

Nutrients were added for $100 \mathrm{~g}$ of soil used in the Winogradsky column according to Anderson and Hairston (1999) with adaptations: $\mathrm{Na}_{2} \mathrm{CO}_{3}(0.2 \mathrm{~g}), \mathrm{Na}_{2} \mathrm{SO}_{4}(4.5 \mathrm{~g}), \mathrm{K}_{2} \mathrm{HPO}_{4}$ (0.5 g), $\left(\mathrm{NH}_{4}\right)_{2} \mathrm{SO}_{4}(0.5 \mathrm{~g})$ and plain paper/cellulose (0.5 g).

The experiment was also kept under illumination. An incandescent lamp (60 W) was placed behind the columns, providing light for the photosynthetic processes. Furthermore, a sheet of paper was maintained to block the top half of the column to evaluate the light incidence and its influence on the microorganism development and heterogeneity. Finally, all columns were covered to prevent insects breeding especially Aedes aegypti, very common in Brazil.

\subsection{Sample analysis}

During the experiment, modifications in the columns were observed such as: algae development and color change. These physical-chemical and microbiological analyses were done just after seven weeks, when the photosynthetic population was stabilized, i.e. there were no more alterations, in three column regions: top, middle and bottom. Besides, it was analyzed: $\mathrm{pH}$, absorbance at $541.5 \mathrm{~nm}$ (Remazol Brilliant Red dye absorbance peak) and algae identification.

Samples were collected close to column walls using a spatula attached to a glass rod and a $100 \mathrm{~mL}$ volumetric pipette and conditioned in test tubes. Subsequently, water and ethanol $70 \%$ were added and sample tubes were kept at low temperature to prevent degradation (Bicudo and Menezes, 2006). Algae identification was done due to this group was more affected by effluent color because being photosynthetic organisms.

Algae were identified using the taxonomic keys by Bicudo and Menezes (2006) and the 
materials (spatula and pipette) were different for each column in order to avoid contamination between them.

\section{Results and Discussion}

\subsection{Algae Development}

Since the beginning of the experiment, algae growth was observed especially in middle part of column A (control), which had the highest light incidence due to dye absence. Moreover, the water was still blurred because the soil had not completely decanted.

At $10^{\text {th }}$ day, there were more intense algae profusion in A, instead of this development was less pronounced in B (contaminated). In both columns, algae have only been found in illuminated part and covered the entire middle of column A. Furthermore, red bacteria appeared in the column A substrate.

After 20 days, the turbidity in A became more evident, while B remained transparent. This fact indicated the effect of dye presence in algal growth. Additionally, algae layer formed on the wall which received direct light incidence shown to be thick and massive in A, while it was thin and formed mostly by points in B.

At 25 days, algae growth had intensified in column A, but in B was less pronounced. Nonetheless, it was observed that the solution became clearer at the bottom of column B, indicating metabolic activity in dye biodegradation.

At $30^{\text {th }}$ day, column A presented algae located in regions without light incidence. On the other hand, there was a froth formation at the top of B that revealed microbial metabolism again. Besides, turbidity differences between the two columns were still noted.

After 30 days, changes in columns had decreased, only showing significant changes at $42^{\text {th }}$ day when turbidity in A reduced and both columns became translucent. Moreover, there was a profusion of filamentous algae in the middle of A. In column B, the forth presence at top and the clearly region at bottom $(7 \mathrm{~cm})$ still indicated continuous metabolic activity by microbiota. At the same time, algae development on the walls of both columns was uniform.

Finally, after 48 days experiment was stopped and the samples were collected for analysis (pH, absorbance and algae identification).

\subsection{Physicochemical Properties}

The water in Winogradsky columns was analyzed by physicochemical methods to evaluated $\mathrm{pH}$ changes and color removal according to incubation time and different regions in the columns.

In column A, $\mathrm{pH}$ remained constant at all points. However, in B the initial $\mathrm{pH}$ was 5.00 and after 48 days changed to: 4.94, 5.02 and 7.00 for top, middle and bottom of the column, respectively. Therefore it was observed higher $\mathrm{pH}$ value at the bottom, which showed increasing microbial activity in the column according to its depth.

Absorbance analysis was performed only in column B due to dye presence. The absorbance 


\section{Macrothink}

measure in Remazol Red Brilliant peak (541.5 nm) at top and bottom was about 0.925 a.u. and 0.890 a.u., respectively (Figure 3a). In Figure 3b, a zoom at $541.5 \mathrm{~nm}$ wavelength was presented and results revealed dye degradation in bottom region of column B.
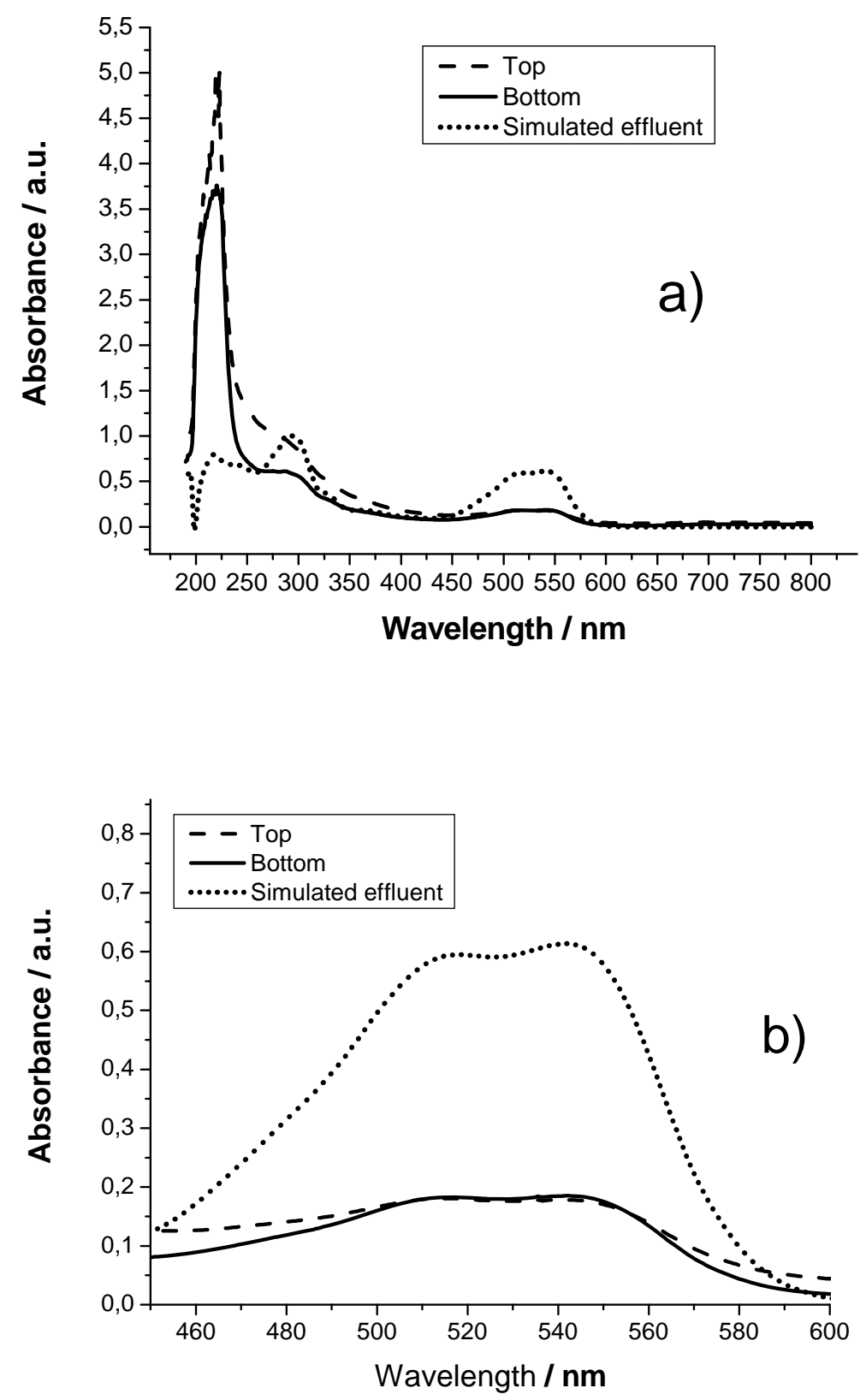

Figure 3. a) Absorbance of the columns, b) Zoom in 541.5 wavelengths

\subsection{Identification of Algae Families}

Taxonomic keys permitted the identification of 12 different algae families in the two columns (A and B). The number of genus found in each family is shown in Table 1. 
Table 1. Algae identified on Winogradsky columns phytoplankton and periphyton

\begin{tabular}{|c|c|c|c|c|c|c|}
\hline & \multicolumn{6}{|c|}{ Number of Genus } \\
\hline Family & \multicolumn{3}{|c|}{ Column A } & \multicolumn{3}{c|}{ Column B } \\
\hline & Top & $\begin{array}{c}\text { Middl } \\
\text { e }\end{array}$ & Bottom & Top & $\begin{array}{c}\text { Middl } \\
\text { e }\end{array}$ & Bottom \\
\hline Bacillariophyceae & 0 & 3 & 1 & 2 & 4 & 3 \\
\hline Chamaesiphonaceae & 0 & 0 & 0 & 1 & 1 & 0 \\
\hline Chlamydomonadaceae & 0 & 0 & 1 & 0 & 0 & 0 \\
\hline Chroococcaceae & 0 & 3 & 2 & 0 & 3 & 0 \\
\hline Desmidiaceae & 0 & 0 & 0 & 0 & 0 & 2 \\
\hline Merismopediceae & 0 & 0 & 0 & 0 & 0 & 1 \\
\hline Microcystaceae & 0 & 1 & 0 & 1 & 1 & 1 \\
\hline Nostocaceae & 0 & 1 & 0 & 0 & 0 & 0 \\
\hline Phormidiaceae & 0 & 1 & 0 & 0 & 0 & 1 \\
\hline Pseudoanabenaceae & 0 & 1 & 0 & 0 & 0 & 0 \\
\hline Volvocaceae & 0 & 0 & 1 & 0 & 1 & 0 \\
\hline
\end{tabular}

Data in Table 1 demonstrates a greater variety of genus in column B. In spite of this, the biomass amount (considering only algae) found in B was much smaller compared to column A.

Nostocaceae incidence only in A was an indicative of the pollution effect presented in B, because this algae family generally not occurs in contaminated environments due to require clean water for its survival (Bicudo and Menezes, 2006).

Nevertheless, Desmidiaceae organisms were just found in Wynogradsky column B owing to these organisms are common in low $\mathrm{pH}$ waters (Reviers, 2006) and can survive in a wide $\mathrm{pH}$ range, as 3.0 to 7.0 (Hoek et al., 1995).

Chlamydomonadaceae has preference for river substrate and appeared significantly at the bottom of A. This family was not found in B because belonged to photosynthetic green algae group and its growth was affected by low light penetration (Reviers, 2006).

Microcystaceae is normally associated to environments with low light incidence, which explain its presence at the top of B and absence at the top of column A (Reviers, 2006). Besides, Microcystaceae algae are related to eutrophic environments (Tundisi and Matsumura-Tundisi, 1992), but results in Table 1 were not conclusive to confirm this since this phenomenon occurrence in areas with many Anabenaceae organisms (Beyruth et al., 1992).

The family with more genus representatives in both Winogradsky columns was Bacillariophyceae, which are generally photosynthetic diatoms but heterotrophic species can be found (Parra and Bicudo, 1995; Bicudo and Menezes, 2006). At the same time, these algae 
are an important primary producer with greater distribution, just after bacteria (Parra and Bicudo, 1995). Bacillariophyceae appearance at the bottom of B may indicate the presence of heterotrophic algae, however their identification by optical microcopy was hard owing to most of pigments and structures can lose their shape quickly after water removal (Parra and Bicudo, 1995).

Futhermore, Bacillariophyciae species are continental water bioindicators and can be used to monitor these environments (Reviers, 2006). Their presence in column B revealed that Remazol Red Brilliant was not highly toxic, but affected the photosynthetic capacity and developments of other algae families as shown in Table 1.

\section{Conclusion}

The results of the two Winogradsky columns (A and B) indicated that Remazol Red Brilliant did not show a high toxicity to algae owing to not inhibit the growth of Bacillariophyceae. However, the dye presence influenced in development of algae commonly found in continental waters as Nostocaceae. Consequently, water turbidity and color in Winogradsky column with Remazol Red Brilliant avoided light incidence and prevented photosynthesis processes by algae. Besides, organisms that preference acidic $\mathrm{pH}$, such as Desmidiaceae ones, occupied the vacant niche left by families more sensitive to pollution.

The presence of Microcystaceae across column B may indicate eutrophization, but by itself is not a conclusive fact. Moreover, the adverse environment caused by dye contamination in B represented a dominance loss of species that needs good lighting as Nostocaceae, enabling the other algae growth.

Nevertheless, despite the greater diversity found in contaminated column (B), algae biomass production was much smaller compared to column without the dye (A). Therefore, Remazol Red Brilliant presence would affect the food chain in aquatic environments and consequently causes an ecological imbalance by the textile effluent impact.

\section{Acknowledgments}

The authors thank FAPESP, CAPES, CNPq and UNESP-Rio Claro for support.

\section{References}

Al-Degs, Y., Khraisheh, M. A. M., Aleen, S. J. \& Ahmad, M. N. (2000). Effect of carbon surface chemistry on the removal of reactive dyes from textile effluent. Water Research, 34, 927-935. http://dx.doi.org/10.1016/S0043-1354(99)00200-6

Anderson, D. C., \& Hairston, R. V. (1999). The Winogradsky column e biofilms: models for teaching nutrient cycling e succession in an ecosystem. The American Biology Teacher, 61, 453-459. http://dx.doi.org/10.2307/4450728

Beyruth, Z., Sant'anna, C. L., Azevedo, M. T. P., Carvalho, M. C., \& Pereira, H. A. S. L. (1992). Toxic algae in freshwaters of São Paulo state. In M. Cordeiro-Marino, M.A. Paiva-Azevedo, C.L. Sant'anna, N.Y. Tomita, \& E.M. Plastino (Eds.), Algae and the enviroment: a general approach (pp. 53-64). São Paulo: Sociedade Brasileira de Ficologia. 
Bicudo, C. E. M., \& Menezes, M. (2006). Algae genus from Brazil's landwater: identification key and descriptions ( $2^{\text {nd }}$. ed.). São Carlos: Rima.

Biggs, B. J. F. (2006). Patterns in benthic algae of streams. In R.J. Stevenson, M.L. Bothwell, \& R.L. Lowe (Eds.), Algal ecology: Freshwater benthic ecosystems (pp. 31-56). Maryland Heights: Academic Press.

Brusca, R. C., \& Brusca, G. J. (2003). Invertebrates ( th $^{\text {th }}$ ed.). Sunderland: Sinauer Associates.

Catanho, M., Malpass, G. R. P., \& Motheo A. J. (2006). Photoelectrochemical treatment of the dye reactive red 198 using DSA1 electrodes. Applied Catalysis B-Environmental, 62, 193-200. http://dx.doi.org/10.1016/j.apcatb.2005.07.011

Hoek, C. V. D., Mann, D. G., \& Jahns, H. M. (1995). Algae: an introduction to phycology $\left(2^{\text {nd }}\right.$. ed.). Cambridge: Cambridge University Press.

Klaine, S. J., \& Lewis, M. A. (1995). Algal and plant toxicity testing - In D.J. Hoffman, B.A. Rattner, G.A. Burton, \& J. Cairns (Eds.), Handbook of ecotoxicology (pp. 13-185). Boca Ratón: Lewis Publishers.

Parra, O. O., \& Bicudo, C. E. M. (1996). Introduction of landwater algae biology and systematic $\left(1^{\text {st }}\right.$ ed.). Santiago: Grafica Andes.

Pérez, J. P. L. (2008). Winogradsky column: an example of basic microbiology in a secondary education laboratory. Revista Eureka sobre enseñanza e divulgación de las ciencias, 5, 373-376.

Pigage, H. K. (1985). The Winogradsky column: A miniature pond bottom. The American Biology Teacher, 47, 239-240. http://dx.doi.org/10.2307/4448027

Reviers, B. (2006). Algae biology and filogeny (1 ${ }^{\text {st }}$ ed.). Porto Alegre: Artmed.

Robinson, T., McMullan, G., Marchant, R., \& Nigam P. (2001). Remediation of dyes in textile effluent: a critical review on current treatment technologies with a proposed alternative. Biosource Technology, 77, 247-255. http://dx.doi.org/10.1016/S0960-8524(00)00080-8

Rocha, A. A. (1992). Algae as biological indicators of water pollution. In M. Cordeiro-Marino, M.A. Paiva-Azevedo, C.L. Sant'anna, N.Y. Tomita, \& E.M. Plastino (Eds.), Algae and the enviroment: a general approach (pp. 34-52). São Paulo: Sociedade Brasileira de Ficologia.

Sousa, M. L., Moraes, P. B., Lopes, P. R. M., Montagnolli, R. N., Angelis, D. F., \& Bidoia, E. D. (2012). Textile dye treated photoelectrolytically and monitored by Winogradsky columns. Environmental Engineering Science, 29, 180-185. http://dx.doi.org/10.1089/ees.2010.0259

Tundisi, J. G., \& Matsumura-Tundisi, T. (1992): Eutrophication of lakes and reservoirs: A comparative analysis, case studies, perspectives. In M. Cordeiro-Marino, M.A. Paiva-Azevedo, C.L Sant'anna, N.Y. Tomita, \& E.M. Plastino (Eds.), Algae and the enviroment: a general approach (pp. 1-34). São Paulo: Sociedade Brasileira de Ficologia. 


\section{Copyright Disclaimer}

Copyright reserved by the author(s).

This article is an open-access article distributed under the terms and conditions of the Creative Commons Attribution license (http://creativecommons.org/licenses/by/3.0/). 